\title{
GIRK2 and neuronal pattern of generation and settling in homozygous weaver mice
}

This article was published in the following Dove Press journal:

Journal of Receptor, Ligand and Channel Research

9 October 2009

Number of times this article has been viewed

\author{
Joaquín Martí1,3 \\ María C Santa-Cruz' \\ Shirley A Bayer ${ }^{2}$ \\ José P Hervás ${ }^{1,3}$ \\ 'Unidad de Citología e Histología, \\ Facultad de Biociencias, Universitat \\ Autònoma de Barcelona, Campus \\ Bellaterra, Spain; ${ }^{2}$ Laboratory \\ of Developmental Neurobiology. \\ Indianapolis, Indiana USA; ${ }^{3}$ Both \\ authors contributed equally to this \\ work
}

\begin{abstract}
G-protein-activated inwardly rectifying potassium (GIRK) channels play an important role in regulating neuronal excitability. Several GIRK channel subunits have been found in the central nervous system. The weaver mutation has been identified as a single base-pair substitution in the gene encoding for a GIRK channel subunit, GIRK2. The cerebellum and the mesencephalon are predominately affected in the homozygous weaver mouse ( $w v / w v)$. In this article, we review our main findings about the patterns of cell generation, survival, and settling of two neuronal types in the $w v / w v$ : Purkinje cells in the cerebellar cortex and dopaminergic neurons in the ventral midbrain. Moreover, we examine if the time of neuron origin determines the degree of cell vulnerability to the lethal action of mutated GIRK2. The possible involvement of other GIRK channel subunits is also considered within the context of earlier and more recent studies in the field.
\end{abstract}

Keywords: Purkinje neurons, dopaminergic neurons, GIRK2, weaver mouse, neurogenetic timetable

\section{Introduction}

Inwardly rectifying potassium channels have dominant control of the membrane potential of mammalian neurons, and modulation of their activity can profoundly influence neuronal excitability. ${ }^{1}$ These potassium channels fall into several subfamilies, one of which is designed as G-protein-activated inwardly rectifying potassium (GIRK) channels. They are also called Kir3 channels and are coupled to a variety of pertussis toxin-sensitive, G-protein linked neurotransmitter receptors that include adrenergic, muscarinic, dopamine, opioid, and $\mathrm{GABA}_{\mathrm{B}}$ receptors. ${ }^{2,3}$ Moreover, GIRK channels are modulated by a wide variety of intracellular factors, such as phosphatidylinositol-4, 5-biphosphate, $\mathrm{Na}^{+}, \mathrm{Mg}^{2+}$, oxidation-reduction, phosphorylation and acidification. ${ }^{3}$ GIRK channels are activated by the $\beta_{\gamma}$ subunit of G-proteins. ${ }^{4}$

Four GIRK channel subunits have been identified in mammals. Of these, GIRK1-GIRK3 exhibit broad and overlapping distribution in the central nervous system (CNS), whereas the fourth subunit, GIRK4, is found primarily in the heart, 5,6 as well as in a few regions of the brain. ${ }^{7}$ These GIRK channel subunits combine to form homo- and heterotetrameric channels both in expression systems and in vivo. ${ }^{8}$ There is evidence that these channels are predominantly heterotetramers formed by both GIRK1 and GIRK2 subunits in most brain regions, as well as homotetramers composed only of GIRK2 subunits. ${ }^{9,10}$ However, the functional relevance of GIRK3 remains uncertain. Several authors have reported that GIRK3 expression, either alone or with other GIRK subunits, failed to yield functional GIRK channels. ${ }^{8,11}$
Correspondence: Joaquín Martí Unidad de Citología e Histología, Facultad de Biociencias, Universitat Autònoma de Barcelona, 08193 Barcelona, Spain Tel $+349358 I 1666$

Fax +349358I 3357

Email joaquim.marti.clua@uab.es 
Yet, GIRK3 directs GIRK1/GIRK2 heterotetramers and GIRK2 homotetramers to lysosomal degradation pathways. ${ }^{12}$ Interestingly, other studies have indicated that recombinant GIRK3 forms operative channels with both GIRK1 and GIRK2. ${ }^{13}$

GIRK proteins are potential sites for genetic mutation inducing neuronal death. In this respect, weaver is a pleiotropic mutation that arose spontaneously over 40 years ago in the C57BL/6J mouse strain. It has been identified as a missense point mutation in the Girk2 gene, which has been cloned and mapped on mouse chromosome 16 in a region homologous (syntenic) to human chromosome 21. ${ }^{14,15}$ When the mouse region was sequenced, it was found that the Girk2 gene encoded a portion of the potassium channel, GIRK2. The difference between normal and weaver GIRK2 protein (GIRK2wv) was one amino acid, a glycine to serine substitution in the middle of a pore-forming of the protein. ${ }^{16}$

In the homozygous weaver mice $(w v / w v)$, high levels of mutated GIRK2 are expressed in several regions of the CNS including the olfactory bulb, hypothalamus, thalamus, midbrain, cerebellum, hippocampus and amygdala..$^{5,17,18}$ Despite this broad distribution, not all neuronal types containing the GIRK2 $w v$ are injured. For example, GIRK2 $w v$ produces no abnormalities in the thalamus and amygdala, whereas in the olfactory bulb and hippocampus, it leads to ectopic and supernumerary cells without any clear functional consequences. ${ }^{19,20}$ Nevertheless, variations in the number of dopaminergic (DA) neurons have been reported in the $w v / w v$ retina during development. ${ }^{21}$

The weaver homozygotes were originally identified at the Jackson Laboratories based on their instability of gait, the most obvious behavioral abnormality, hence the origin of the name weaver. In mice, gait abnormalities generally imply cerebellar defects and, for many years, study of the pathology disturbance caused by GIRK $2 w v$ focused entirely on the cerebellum. This, in fact, is miniaturized due to the huge loss of granule cells (GCs). ${ }^{22,23}$ Furthermore, there are also substantial deficiencies in Purkinje cells (PCs) and deepcerebellar nuclei neurons. ${ }^{24-26}$

Other alterations in the weaver cerebellum include: ectopic location of the surviving neurons; ${ }^{27-29}$ a disturbed foliar pattern in the hemispheres, although similar to that seen in control mice $(+/+)$ at the vermis level; ${ }^{28-30}$ and altered cytoarchitecture of the cerebellar cortex (Rakic and Sidman 1973a). ${ }^{23}$ Moreover, degeneration of $w v / w v$ pontocerebellar mossy fibres has been found. ${ }^{31}$

There is still a debate about the causes that produce this GC loss. At least two models have been proposed (revised in
Harkins and Fox $^{2}$ ). In the first model, the weaver condition leads to a constitutively active GIRK2 channel, which results in loss of selectivity for $\mathrm{K}^{+}$allowing $\mathrm{Na}^{+}$and $\mathrm{Ca}^{2+}$ to penetrate cells. Neuronal death is related to the elevated intracellular $\mathrm{Ca}^{2+}$ levels caused by continuous depolarization. The second model proposes the loss of the GIRK $2 w v$ channel function, which reduces a major inhibitory pathway in developing neurons, producing GC hyperexcitability and cell death.

In addition to ataxia, the weaver homozygotes also exhibit mild locomotor hyperactivity, ${ }^{32}$ a behavioral phenotype often associated with abnormalities in dopaminergic neurotransmission. The effect of GIRK $2 w v$ on the mesostriatal system remained unnoticed until the measurement of dopamine demonstrated severe transmitter loss in the weaver forebrain. ${ }^{33,34}$ Subsequent studies reported an important depletion of DA neurons in midbrain areas, with the substantia nigra pars compacta (SNc) being the most severely affected region. ${ }^{35-37}$

In this paper, our main findings since the 1990s are summarized and considered within the context of the most relevant literature about the weaver mouse. We also discuss the way that GIRK2wv might affect the patterns of generation, survival and settling of PCs and several midbrain groups of DA neurons. The relevance of this review is that it attempts to link the lethal action of the GIRK $2 w v$ with the temporal and spatial patterns of neuron formation, while the possible involvement of other GIRK channel subunits is also considered.

\section{Materials and methods Experimental design}

All experiments were carried out in accordance with the requirements of the Committee for Institutional Animal Care and Use. Mice used in our experiments were obtained from the colony of $+/+$ and $w v / w v$ at Indiana University School of Medicine, maintained on the B6CBA-A $\mathrm{A}^{\mathrm{w}-\mathrm{j}} / \mathrm{A}$ hybrid stock. The morning after mating was considered embryonic day (E) 1, whereas the day of birth was postnatal day (P) 0. During experimental procedures, dams and litters were maintained under controlled conditions. Food and water were always provided ad libitum. Pregnant dams ( $w v /+$ or $w v / w v)$, previously mated with $w v /+$ males, were injected subcutaneously on two successive days in an overlapping series with $\left[{ }^{3} \mathrm{H}\right] \mathrm{TdR}(5 \mu \mathrm{Ci} / \mathrm{g}$ of body weight, New England Nuclear \#NET-027), according to the following embryonic time-windows: E11-12, E12-13, E13-14 and E14-15. Pups were perfused through the heart with $10 \%$ (vol/vol) neutral buffered formalin on P8, P20 and P90. The blocks containing the cerebellum and the 
midbrain were dehydrated, paraffin-embedded and sectioned at $10 \mu \mathrm{m}$ in the sagittal and coronal plane, respectively.

\section{Tyrosine hydroxylase immunocytochemistry}

Tyrosine hydroxylase (TH) immunocytochemistry (to detect DA neurons) was applied to brain sections following a previously described procedure. ${ }^{38}$ Basically, this consisted of incubated sections with rabbit anti-TH antiserum (Eugene Tech International, Allendale, NJ, USA) 1:1600 in TBS. After the first antibody incubation, a second one with a goat antirabbit IgG was carried out (Amersham, UK) at 1:20, followed by a further incubation with rabbit PAP complex. Finally, sections were reacted with 3,3'-diaminobenzidine- $\mathrm{H}_{2} \mathrm{O}_{2}$. Control sections were prepared by replacing the primary antibody with tris-buffered saline. TH-reactive neurons were defined as those displaying a brown reaction product in their cytoplasms.

\section{$\left[{ }^{3} \mathrm{H}\right]$ thymidine autoradiography}

After the TH-immunocytochemistry was completed, $\left[{ }^{3} \mathrm{H}\right] \mathrm{TdR}$ autoradiography was undertaken using the same sections. Slices containing cerebellar tissue were also processed for autoradiography. In both cases, isotope incorporation was detected as previously described. ${ }^{38}$ Briefly, slides coated with liquid photographic emulsion were stored in light-tight boxes at $4{ }^{\circ} \mathrm{C}$ for an exposure time of 12 weeks. Subsequently, they were lightly post-stained with hematoxylin, dehydrated and cover-slipped with Permount. All slices were simultaneously processed to avoid variations between groups in different batches. Examples of labeled PCs and DA cells are shown in Figures 1 and 2, respectively.

\section{Cell recordings}

Labeled and unlabeled PCs were separately scored in the mediolateral $^{26}$ and anteriorposterior axes ${ }^{39}$ of the $+/+$ and $w v / w v$ cerebellum. In the same rostrocaudal axis, PCs were also counted in both the fissures and the superficial (convex) areas of each cerebellar folium. ${ }^{40}$ The names of lobes and lobules, as well as their limits, were those assigned by Altman and Bayer. ${ }^{41}$

Criteria for scoring PCs included the presence of a large and clear nucleus, pear-shaped cell body, and their position between the molecular and granular cell layers. As $w v / w v$ PCs somata are ectopically settled, due to disruption of the normal cerebellar cortex cytoarchitecture, ${ }^{28,29}$ it might be difficult to distinguish between PCs and any other large neurons in our haematoxylin counterstained sections. Total PC counts in the
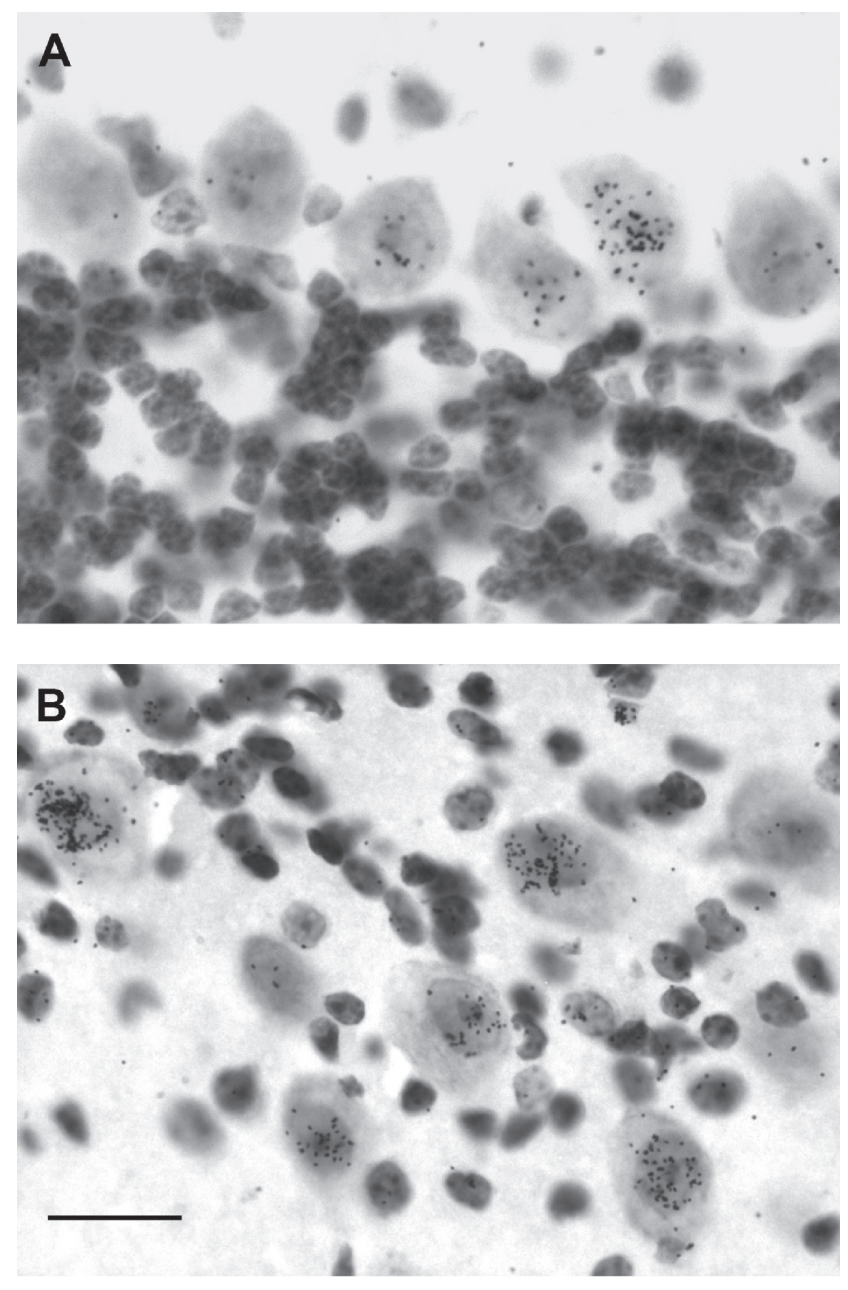

Figure I High-magnification autoradiograms at the level of the vermal anterior lobe of the cerebellum from a $+/+(\mathbf{A})$ and a weaver mouse $(\mathbf{B})$ exposed to $\left[{ }^{3} \mathrm{H}\right] \mathrm{TdR}$ at EI2-13 and surviving to P90. Labeled Purkinje cells can be identified by the presence of nuclear black dots. Scale bar, $20 \mu \mathrm{m}$.

mutant were therefore multiplied by a Golgi-cell correction factor $(85.7 \%)$. This factor was introduced by Lange ${ }^{42}$ and has been used in quantitative analyses of weaver PCs. ${ }^{24}$

$\left[{ }^{3} \mathrm{H}\right] \mathrm{TdR}$-labeled and unlabeled DA neurons were separately scored in four $+/+$ and $w v / w v$ midbrain regions: the substantia nigra pars compacta $(\mathrm{SNc})$, the ventral tegmental area (VTA), the interfascicular nucleus (IFN) and the retrorubral field (RRF). Numbers of SNc DA neurons were also recorded at four anteroposterior (AP) coronal levels (L1 to L4) along $+/+$ and $w v / w v$ SNc. The VTA DA cells were counted from L2 to L4. Figure 3 shows the chosen anatomical levels, which are based on plates $46,50,54,58$ and 60 in the atlas of Sidman and colleagues. ${ }^{43}$

\section{Quantitative analyses}

Cell counts (PCs and DA neurons) were carried out at 400X using a Leitz microscope with a $10 \times 10$ reticule in one of 

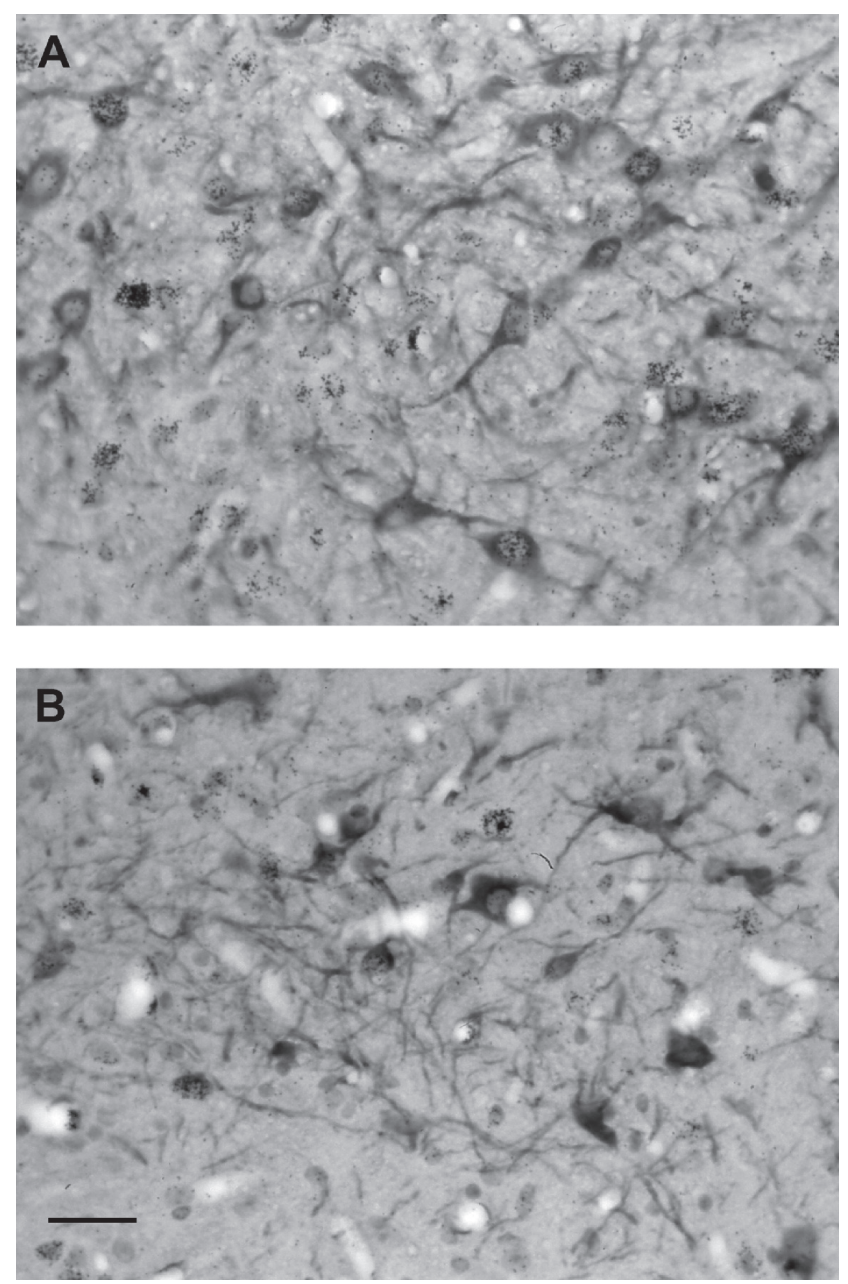

Figure 2 High-magnification autoradiograms of TH-immunostained sections (darker reaction product in cytoplasm) through the midbrain of a $+/+(\mathbf{A})$ and a weaver mouse (B) injected with $\left[{ }^{3} \mathrm{H}\right] \mathrm{TdR}$ at EI2-13 and killed at P90. Both photomicrographs correspond to the retrorubral field. $\left[{ }^{3} \mathrm{H}\right] \mathrm{TdR}$-labeled neurons can be identified by the presence of nuclear black dots. Note the relative decrease in cell density in the weaver image. Scale bar, $30 \mu \mathrm{m}$.

the eyepieces. The frequency of $\left[{ }^{3} \mathrm{H}\right] \mathrm{TdR}$-labeled neurons was calculated as a percentage, by dividing the number of labeled neurons with the total number of neurons scored. Neurogenetic programs were inferred by subtracting the percentage of labeled neurons in a given embryonic timewindow from the percentage of the immediately previous $\left[{ }^{3} \mathrm{H}\right] \mathrm{TdR}$ injection window, in order to obtain the fraction of neurons generated between the two injection series. As pilot data from injections on E10-11 indicated that nearly all +/+ or $w v / w v$ PCs and TH neurons are labeled with $\left[{ }^{3} \mathrm{H}\right] \mathrm{TdR}$, no mice were tested during this time-window. A value of $100 \%$ was assumed for both genotypes. In contrast, at E15-16, the percentage of labeled PCs and TH-positive neurons was very low; again, no animals were injected at this time-window and a value of $0 \%$ was established for both $+/+$ and $w v / w v$.
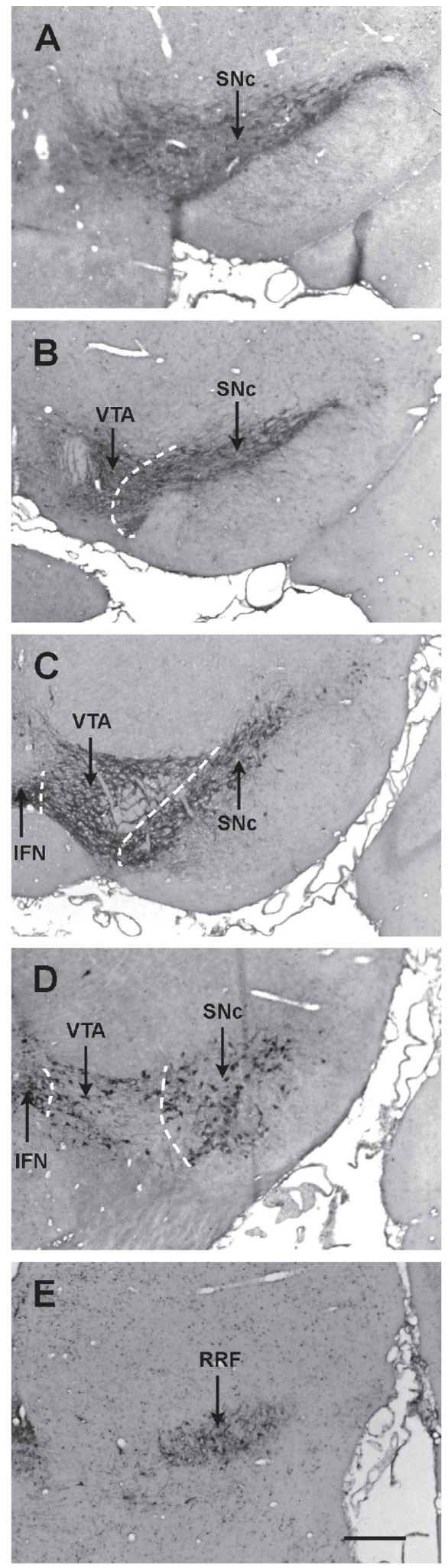

Figure 3 Representative low-magnification view of five coronal sections used for cell counting in the SNc, VTA, IFN and RRF from control mice that survived until P90. Sections A to D correspond to LI-L4 anatomical levels; B-D Copyright (C) 2007, Elsevier. Adapted with permission from Martí J, Santa-Cruz MC, Bayer SA, Ghetti B, Hervás JP. Generation and survival of midbrain dopaminergic neurons in weaver mice. Int J Devl Neurosci. 2007;25(5):299-307.

Notes: White broken lines delimit the regions studied in the right side of the ventral midbrain. Scale bar, $300 \mu \mathrm{m}$. 
Subsequently, the neurogenetic gradients of the studied neurons were established by examination of the neurogenetic timetables. The term neurogenetic gradient refers to the nonrandom spatial accumulation of cells according to age within and between neuronal populations. ${ }^{44}$

\section{Statistical analysis}

Data analyses were carried out using SPSS (version 14, SPSS Inc, Chicago, IL, USA) statistical software. Comparisons between means were made using the Student's $t$-test if variances were homogeneous in accordance with the $F$-test, whereas the Mann-Whitney $U$-test was used if the variances were not homogeneous after $\log$ transformation. A ' $P$ ' value of less than 0.05 was considered statistically significant.

\section{Results}

\section{Initial loss of weaver Purkinje cells}

Early studies revealed that, around E19, PC loss was detectable in the cerebellar vermis of mutant embryos, ${ }^{45}$ and in the same region we have recently reported a decrease in PC numbers by more than $40 \%$ at $\mathrm{P} 8 .{ }^{46}$ At this age, the generative period of such macroneurons presented the same duration in $+/+$ and $w v / w v$ cerebella (data not shown). Moreover, no differences in the neurogenetic program were found between the two genotypes. When these results were compared with those of the adult mutant mouse, ${ }^{26}$ it was clearly shown that no differential loss of PCs occurs between P8 and P90 weaver vermis.

\section{Surviving weaver PCs along the cerebellar axes}

The loss of PCs is not uniformly distributed across the weaver cerebellum. Indeed, this loss is severe in the vermis, but very limited in the hemispheres. ${ }^{28,29}$ Therefore, does regional delivery of PCs alter in the weaver condition? To answer this question, we designed some experiments in $+/+$ and $w v / w v$ mature mice following two topographic coordinates: the mediolateral and anteroposterior axes of the cerebellum.

In the first case, ${ }^{26}$ cell counts were carried out in the four successive cerebellar compartments assigned by Altman and Bayer: ${ }^{41}$ vermis, paravermis, medial and lateral hemispheres. When the relative loss of $w v / w v$ PCs for these compartments was compared, the numerical deficit was highest in the vermis, lower in the paravermis and lowest in the medial hemisphere, whereas in the lateral hemisphere the number of surviving PCs was similar to that of $+/+$. Yet, quantification of autoradiograms showed that every peer of $\left[{ }^{3} \mathrm{H}\right] \mathrm{TdR}$ injections, at specific embryonic days (see Materials and methods), labeled approximately the same number of PCs in each cerebellar compartment of $+/+$ and $w v / w v$ mice. Consequently, the onset of neurogenesis, its total span and the neurogenetic program were similar in both experimental groups, as well as in each analyzed region (data not shown). Such a generative timetable enabled us to differentiate between early- and late-born PCs. As Table 1 shows, these macroneurons were generated in both genotypes according to a lateral-to-medial gradient; thus, the lateral hemisphere contains more early-generated neurons than the vermis, which in turn has more late-formed neurons than lateral hemispheres. Hence, we were able to supply solid evidence that the weaver mutation does not interfere with the production and settling patterns of surviving PCs along the cerebellar mediolateral extension.

Subsequent experiments were undertaken on the rostrocaudal axis of both the vermis and the lateral hemisphere. ${ }^{39}$ Counts and timetables of PCs were separately determined in each vermal lobe and in the simplex, ansiform and paramedian hemispheric lobules. Results showed that PC neurogenetic programs were similar for $+/+$ and $w v / w v$ in each analyzed region of the vermis (Figure 4) and the hemisphere (data not shown). The neurogenetic gradients of these macroneurons were also compared. As shown in Tables 2 and 3, they are very much alike between wild-type and weaver for each vermal lobe or hemispheric lobule considered. Interestingly, in both genotypes, the vermal central or posterior lobes are made up of more early-generated PCs than any other lobe (Table 2), while a rostrocaudal decrease in old PCs can be observed throughout the hemispheric lobules (Table 3). Nevertheless, all these data demonstrate that the age-distribution of surviving PCs carrying the mutant allele remains unaltered. Yet, when the loss of $w v / w v$ PCs was assessed, the central lobe appeared to be the most affected vermal region (41.4\% vs $+/+$ value). Moreover, there was a substantial deficit in the simplex and paramedian hemispheric lobules

Table I Percentage of early and late generated PCs in each compartment of the cerebellar cortex

\begin{tabular}{llllll}
\hline Compartment & \multicolumn{2}{c}{ Older (EI 0-I 2) } & & \multicolumn{2}{c}{ Younger (E |3-I 4) } \\
\cline { 2 - 3 } \cline { 6 - 6 } & $+l+$ & wv/wv & & $+1+$ & wv/wv \\
\hline Vermis & 63.7 & 66.4 & & 36.3 & 33.6 \\
Paravermis & 67.9 & 71.6 & & 32.1 & 28.4 \\
M. hemisphere & 73.0 & 74.2 & & 27.0 & 25.8 \\
L. hemisphere & 76.7 & 73.9 & & 23.3 & 26.1 \\
\hline
\end{tabular}

Notes: PCs generated from EIO to EI 2 are considered early-generated, whereas those originated at EI3 and EI4 are late-generated. Copyright (C) 200I, Elsevier. Adapted with permission from Martí J, Wills KV, Ghetti B, Bayer SA. Evidence that the loss of Purkinje cells and deep cerebellar nuclei neurons in homozygous weaver is not related to neurogenetic patterns. Int J Devl Neurosci. 200I;19:599-610. 


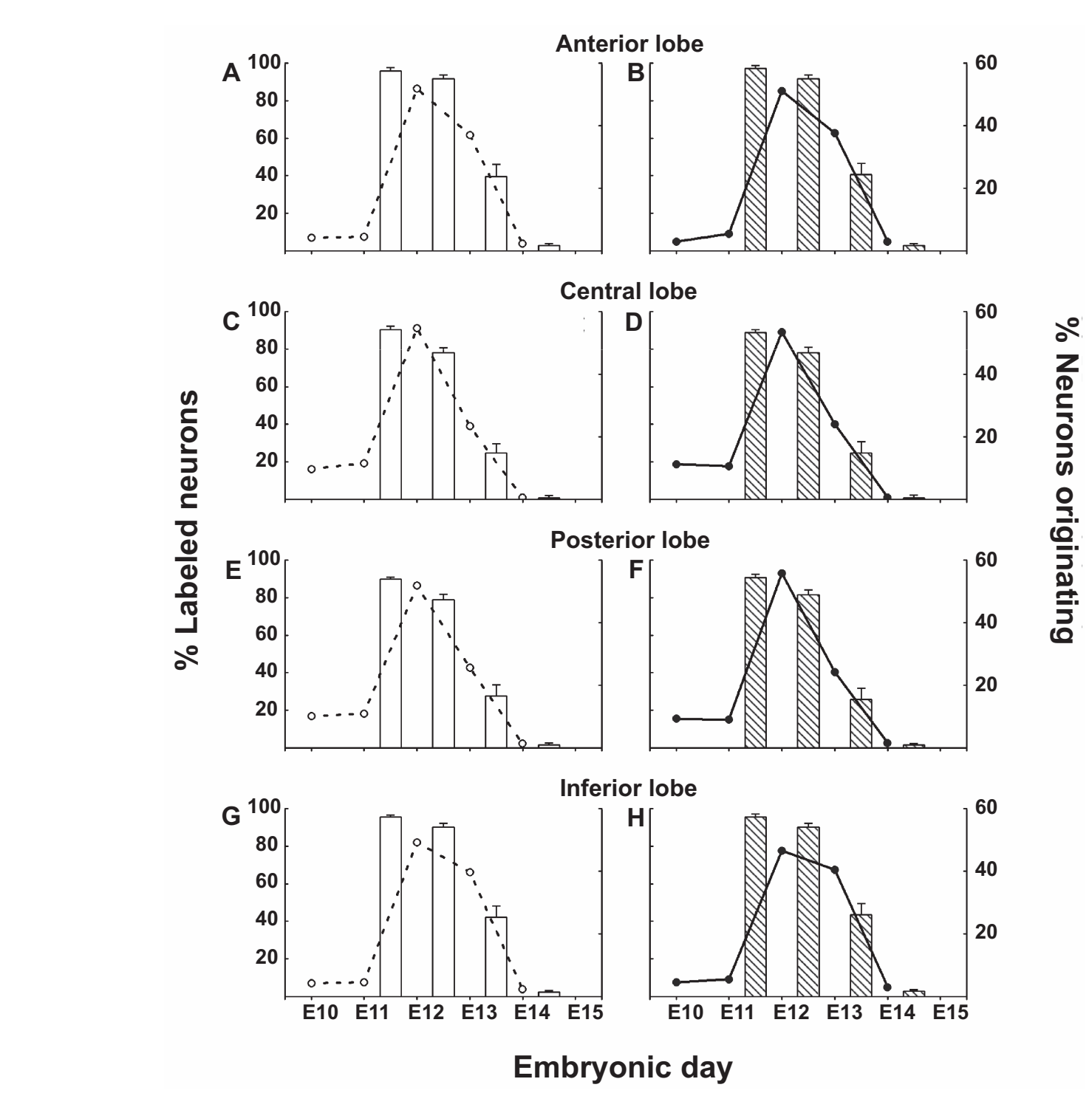

Figure 4 Comparison of generative timetables between wild-type and weaver PCs at the level of the anterior $(\mathbf{A}, \mathbf{B})$, central $(\mathbf{C}, \mathbf{D})$, posterior $(\mathbf{E}, \mathbf{F})$ and inferior $(\mathbf{G}, \mathbf{H})$ cerebellar vermal lobes. Frequency histograms (left ordinate) of PCs labeled with $\left[{ }^{3} \mathrm{H}\right] \mathrm{TdR}$ on two successive days of the embryonic period (abscissa) and surviving until P90. Empty and shared columns represent $+/+$ and $w v / w v$ respectively; percentages are expressed as mean \pm SEM. The inferred frequencies of newly generated PCs for $+/+($ open circles and broken line) and wv/wv (closed circles and solid lines) are also plotted. Percentages of these newborn neurons (right ordinate) were determined by the rate of decline in labeled cells at that time point. Data from Martí and colleagues. ${ }^{39}$

(64.6\% and $60.4 \%$, respectively), although as a whole, the lateral hemisphere did not present a lower number of PCs than control.

\section{Purkinje cell age-distribution}

\section{and cerebellar fissuration}

Finally, another comparative study of PC generation and survival between $+/+$ and $w v / w v$ mice was undertaken to determine possible relationships with the cerebellar fissuration pattern. ${ }^{40}$ Separate analyses were carried out for each vermal lobe and hemispheric lobule at P90, with a distinction being made between fissures and foliar crowns. Our first observation was that in the grooves, as well as in the creases of every vermal lobe (Figure 5) or hemispheric lobule (data not shown), the neurogenetic programs of weaver PCs closely resembled those of the wild-type group. The neurogenetic gradients of these macroneurons were also estimated for both genotypes (Table 4). They revealed the accumulation of late-generated PCs in fissures, whereas older PCs were concentrated in the foliar crowns, that is, there appears to be a similar birthdate gradient in each $+/+$ and $w v / w v$ particular lobe, or lobule. Moreover, differences and similarities in PC age-distribution were evident throughout the cerebellar surface contour. As seen in Table 4, the frequencies of young PCs 
Table 2 Percentage of generated Purkinje cells in the cerebellar vermis

\begin{tabular}{llllll}
\hline Vermal lobes & \multicolumn{2}{c}{ Older (EI 0-I 2) } & & \multicolumn{2}{c}{ Younger (EI3-I4) } \\
\cline { 2 - 3 } \cline { 6 - 7 } & $+l+$ & wv/wv & & $+l+$ & wv/wv \\
\hline Anterior & 60.5 & 59.4 & & 39.5 & 40.6 \\
Central & 76.0 & 75.2 & & 24.0 & 24.8 \\
Posterior & 73.0 & 74.2 & & 27.0 & 25.8 \\
Inferior & 57.9 & 56.5 & & 42.1 & 43.5 \\
\hline
\end{tabular}

Notes: PCs generated from EIO to EI2 are considered early-generated, whereas those originating at EI3 and EI4 are late-generated. Data were obtained from Figure 4. Copyright (C) 2002, Elsevier. Adapted with permission from Martí J, Wills KW, Ghetti B, Bayer SA. Regional differences in the Purkinje cells settled pattern: a comparative autoradiographic study in control and homozygous weaver mice. Exp Neurol. 2002; 175:168-181.

settled in fissures of the anterior and inferior vermal lobes are higher than those for the fissures of the central and posterior lobes. Nevertheless, most earlier-formed PCs are found in loci facing convex surfaces of the central and posterior lobes. In the lateral hemisphere, there seems to be an almost uniform distribution of early PCs facing fissures and foliar crowns of the simplex as well as the ansiform lobule. However, the percentage of late-formed neurons located at fissures is higher in the paramedian than in the rest of the hemispheric lobules. Our results again clearly show that surviving PCs were able to migrate toward their final destinations, concavities or convexities, in the $w v / w v$ cerebellar cortex.

Although we only present here the results for the vermis region, depletion of PCs in weaver cerebella was also estimated for fissures and foliar crowns of both the vermis and the lateral hemisphere. As indicated in Table 5, there is a statistically significant decrease in PC numbers in both the concave and convex surfaces of each $w v / w v$ vermal lobe. Thus, in the anterior lobe, neuronal loss is much more severe in the loci of foliar crowns (with $34.2 \%$ of cells remaining

Table 3 Percentage of generated Purkinje cells in the cerebellar hemispheres

\begin{tabular}{|c|c|c|c|c|}
\hline \multirow{2}{*}{$\begin{array}{l}\text { Hemispheric } \\
\text { lobule }\end{array}$} & \multicolumn{2}{|c|}{ Older (EI0-I2) } & \multicolumn{2}{|c|}{ Younger (EI3-|4) } \\
\hline & $+l+$ & $w v / w v$ & $+1+$ & $w v / w v$ \\
\hline Simplex & 83.1 & 84.7 & 16.9 & 15.3 \\
\hline Ansiform & 79.3 & 79.8 & 20.7 & 20.2 \\
\hline Paramedian & 61.5 & 64.9 & 38.5 & 35.1 \\
\hline Summed average & 74.6 & 76.5 & 25.4 & 23.5 \\
\hline
\end{tabular}

Notes: PCs generated from EIO to EI 2 are considered early-generated, whereas those originating at EI3 and EI4 are late-generated. Copyright (C) 2002, Elsevier. Adapted with permission from Martí J, Wills KW, Ghetti B, Bayer SA. Regional differences in the Purkinje cells settled pattern: a comparative autoradiographic study in control and homozygous weaver mice. Exp Neurol. 2002; 175:168-181. as compared to control) than in those facing fissures (with $62.4 \%$ of cells remaining as compared to control). Moreover, the relative amount of $w v / w v$ PCs corresponding to these fissures is greater than in any other vermal locality. The central lobe exhibits a similar depletion of PCs in its grooves (37.1\% of cells remaining) and crests (34.8\%). In line with these results, neuronal loss in the posterior lobe seems to affect concave or convex surfaces almost equally. When these macroneurons are scored in the inferior lobe, there is a larger reduction in the zones lying on fissures than at the lobar crown (with only $49.2 \%$ of cells remaining vs $60.4 \%$ at the lobar crown, relative to controls). In short, severity in PC loss also seems to depend on the foliar compartment analyzed.

\section{Initial loss of weaver dopaminergic neurons}

Compared to wild-type, the weaver homozygote presents a reduction in the number of DA cells in several areas of the ventral midbrain. ${ }^{35,47}$ However, there is evidence that $w v / w v$ mice are born with a normal complement of DA cells ${ }^{48}$ which is subsequently lost during postnatal life. The timing of neuronal vulnerability to gene mutation may vary between different midbrain regions, hence, numerical deficits have been reported at P14 in the SNc, ${ }^{36}$ but at P20 in the RRF. ${ }^{47}$ In an attempt to gain more information about the time-course depletion of DA neurons, and its possible relationship with the age of these cells, a set of experiments were undertaken in four midbrain areas, the SNc, VTA, IFN, and RRF, considering each of them as a whole.

\section{Viability of weaver DA cells in early postnatal days}

Firstly, counts and origin-timetables of DA cells were determined in each area mentioned above of $+/+$ and $w v / w v$ mice at P8.$^{49}$ No cell loss was found in any of these neuronal populations (Table 6), that is, $w v / w v$ DA neurons were still alive at that age. The inferred neurogenetic programs were similar between $+/+$ and $w v / w v$ in each midbrain area analyzed (data not shown) and, irrespective of the genotype, DA neurons in the RRF seemed to be the earliest generated, followed by those in the SNc, the VTA and finally the IFN. In addition, the cytoarchitecture of these cell populations was also the same in both experimental groups. All these results suggest that the proliferative behavior of DA-cell precursors, as well as subsequent steps in the neuronal development (eg, cell migration, axonal outgrowth and neuronal settling), seem to be unaffected by the expression of the weaver gene. 

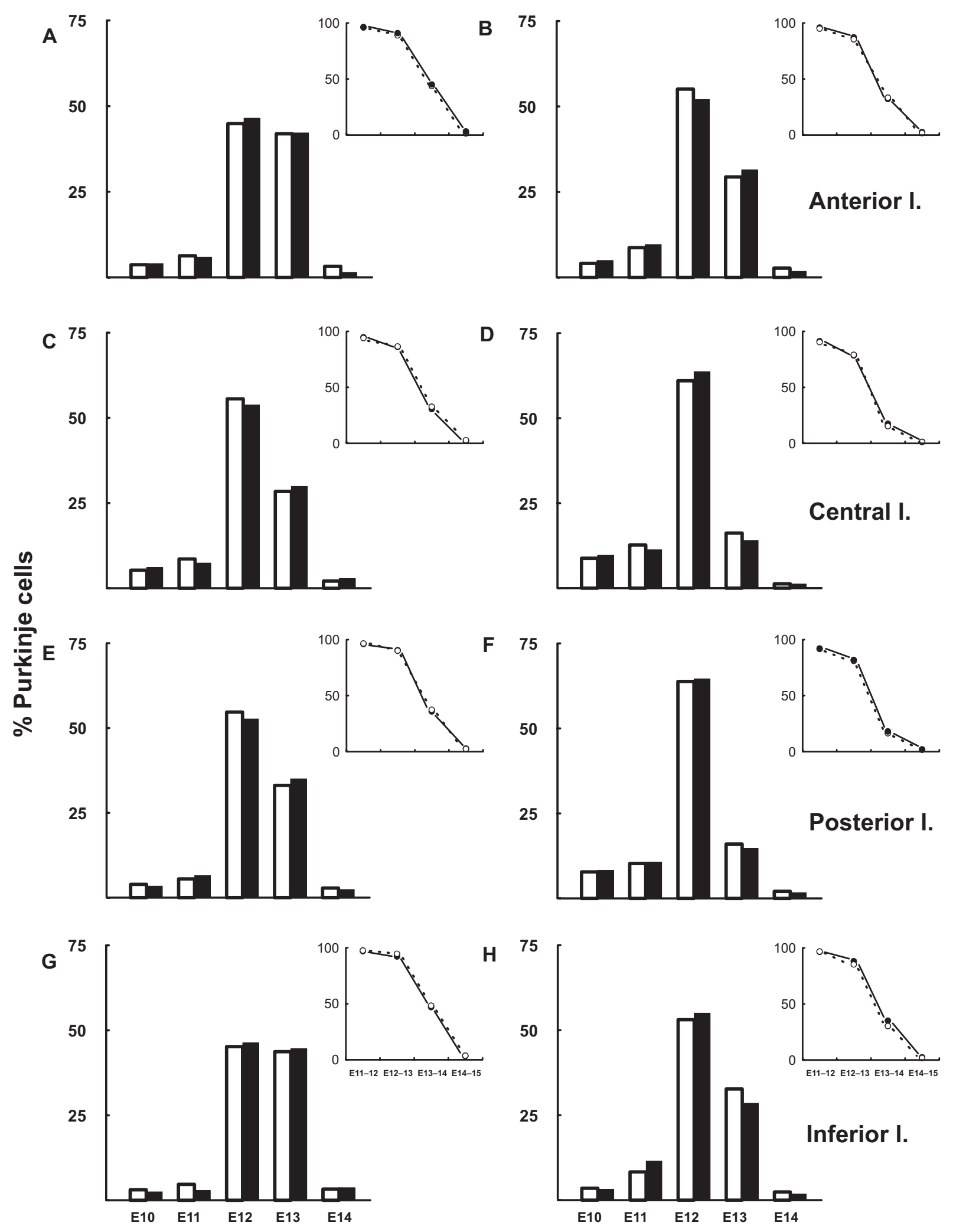

Time (embryonic days)

Figure $\mathbf{5}$ Comparison of generative timetables between wild-type and weaver PCs in fissures $(\mathbf{A}, \mathbf{C}, \mathbf{E}, \mathbf{G})$ and foliar crowns (B, D, F, H) of the anterior $(\mathbf{A}, \mathbf{B})$, central $(\mathbf{C}, \mathbf{D})$, posterior $(\mathbf{E}, \mathbf{F})$ and inferior $(\mathbf{G}, \mathbf{H})$ cerebellar vermal lobes. The insets graphically show the frequencies of $\mathrm{PCs}$ labeled with $\left.{ }^{3} \mathrm{H}\right] \mathrm{TdR}$ on successive time-windows of the embryonic period and surviving until P90. Data points represent mean percentages for $+/+$ (closed circles and solid line) and wv/wv (open circles and broken line) labeled PCs, respectively. The inferred birth sequences of PCs vs time for $+/+$ (empty columns) and wv/wv (solid columns) are plotted in the main graphs. Percentages of these newborn neurons were determined by the rate of decline in labeled cells at that time point. Data from Martí and colleagues. ${ }^{40}$ 
Table 4 Frequency of generated Purkinje cells

\begin{tabular}{|c|c|c|c|c|c|c|c|c|}
\hline \multirow[t]{3}{*}{ Cerebellar level } & \multicolumn{4}{|c|}{ Fissures } & \multicolumn{4}{|c|}{ Foliar crowns } \\
\hline & \multicolumn{2}{|c|}{$\begin{array}{l}\text { Old PCs } \\
(\text { EIO + EII) }\end{array}$} & \multicolumn{2}{|c|}{$\begin{array}{l}\text { Young PCs } \\
\text { (EI3 + EI4) }\end{array}$} & \multicolumn{2}{|c|}{$\begin{array}{l}\text { Old PCs } \\
(\text { EIO + EII) }\end{array}$} & \multicolumn{2}{|c|}{$\begin{array}{l}\text { Young PCs } \\
\text { (EI3 + EI4) }\end{array}$} \\
\hline & $\overline{+l+}$ & $w v / w v$ & $+1+$ & $w v / w v$ & $+1+$ & $w v / w v$ & $+1+$ & $w v / w v$ \\
\hline \multicolumn{9}{|l|}{ Vermal lobes } \\
\hline Anterior & 10.0 & 9.9 & 45.1 & 43.6 & 12.8 & 14.6 & 32.1 & 33.3 \\
\hline Central & 13.9 & 13.5 & 30.5 & 32.7 & 21.5 & 21.0 & 17.5 & 15.3 \\
\hline Posterior & 9.4 & 9.9 & 35.9 & 37.4 & 18.1 & 19.0 & 18.1 & 16.4 \\
\hline Inferior & 7.8 & 5.4 & 47.0 & 48.3 & 11.8 & 14.7 & 35.1 & 30.3 \\
\hline \multicolumn{9}{|l|}{ Hemisphere lobules } \\
\hline Simplex & 15.2 & 15.7 & 24.2 & 22.9 & 17.7 & 16.4 & 9.6 & 12.7 \\
\hline Ansiform & 14.8 & 14.8 & 27.2 & 24.9 & 16.0 & 15.0 & 12.8 & 12.0 \\
\hline Paramedian & 6.4 & 6.9 & 47.4 & 46.0 & 15.4 & 13.8 & 29.6 & 27.4 \\
\hline
\end{tabular}

Notes: Percentage of early and late-produced PCs at the level of the vermis and in the lateral hemisphere. PCs formed at EI0 + EII are considered early-generated, whereas those originating at EI3 + El4 are late-generated. Vermal values were obtained from Figure 5. Copyright @ 2007, Springer Science + Business Media. Adapted with permission from Martí J, Santa-Cruz MC, Bayer SA, Ghetti B, Hervás JP. Purkinje cell age-distribution in fissures and in foliar crowns: a comparative study in the weaver cerebellum. Brain Struct Funct. 2007;2 12:347-357.

\section{Generative profiles of weaver surviving DA cells}

Secondly, when the weaver midbrain was studied at P90, an important deficit of DA neurons was found in three of the analyzed areas. As shown in Table 6, cell loss was highest in the SNc, lower in the VTA and lowest in the RRF. Moreover, comparisons with data from earlier ages (P8 and P20) reveal a progressive decrease in cell numbers for the SNc and VTA. The numerical deficit in the RRF does not strictly follow this trend, although the hybrid background of $w v / w v$ breeding stocks may account for that variability. The generative timetable of each DA-cell group was also compared between the two genotypes. As can be see in Figure 6, wv/wv DA neurons exhibit the same duration of neurogenesis as $+/+$ for each analyzed area, with it ending at E13 for the RRF but being prolonged until E14 for both the SNc and VTA. Yet, there were systematic differences in each particular neurogenetic program. The peak of the profile for newborn DA neurons is reached toward E12 in $+/+\mathrm{SNc}$ and RRF, while E11 represents the highest generative point for both weaver areas. A shift to earlier embryonic days can also be observed in the $w v / w v$ VTA profile. Bearing in mind the previously mentioned cell loss found in these three midbrain areas, a possible hypothesis could be that surviving DA neurons are more likely to be generated earlier than later.

\section{Spatial differences in the vulnerability of weaver DA cells}

Finally, generation and survival of weaver DA neurons were again studied in the SNc and VTA at P90, but with a distinction being made between the four coronal anatomical levels (L1 to L4) along the AP extent of both DA-cell groups. ${ }^{51}$ Figure 3 shows the chosen consecutive levels (see also Materials and methods). Our initial results concern

Table 5 Purkinje cell counts per section in the vermis

\begin{tabular}{|c|c|c|c|c|c|c|}
\hline \multirow[t]{2}{*}{ Lobe } & \multicolumn{3}{|l|}{ Fissures } & \multicolumn{3}{|c|}{ Foliar crowns } \\
\hline & $+1+$ & $w v / w v$ & $\begin{array}{l}\text { wv\% } \\
\text { control }\end{array}$ & $+1+$ & $w v / w v$ & $\begin{array}{l}\text { wv\% } \\
\text { control } \\
\end{array}$ \\
\hline Anterior & $289.3 \pm 5.1$ & $180.6 \pm 6.3^{a}$ & 62.4 & $94.5 \pm 8.1$ & $32.3 \pm 6.8^{b}$ & 34.2 \\
\hline Central & $165.8 \pm 4.8$ & $61.5 \pm 5.6^{\mathrm{a}}$ & 37.1 & $79.6 \pm 5.9$ & $27.7 \pm 5.8^{\mathrm{b}}$ & 34.8 \\
\hline Posterior & $69.7 \pm 5.3$ & $34.7 \pm 5.1^{\mathrm{a}}$ & 49.8 & $33.9 \pm 6.2$ & $18.8 \pm 5.8^{c}$ & 55.5 \\
\hline Inferior & $38.0 \pm 3.6$ & $18.7 \pm 5.3^{\mathrm{a}}$ & 49.2 & $25.8 \pm 2.6$ & $15.6 \pm 2.5^{c}$ & 60.4 \\
\hline
\end{tabular}

Notes: Values are expressed as mean \pm SEM from each vermal lobe of the cerebellar cortex. Counts were done in the EI4-15 $\left[{ }^{3} \mathrm{H}\right] \mathrm{TdR}$ injection series. ${ }^{\mathrm{a} P}<0.005$, ${ }^{\mathrm{b}} \mathrm{P}<0.00 \mathrm{I}$, cp < 0.05 compared to +/+ (Student's t-test). Copyright @ 2007, Springer Science + Business Media. Adapted with permission from Martí J, Santa-Cruz MC, Bayer SA, Ghetti B, Hervás JP. Purkinje cell age-distribution in fissures and in foliar crowns: a comparative study in the weaver cerebellum. Brain Struct Funct. 2007;2I2:347-357. 
Table 6 Percentages of $w v / w v$ dopaminergic neurons in relation to that of wild-type values

\begin{tabular}{llll}
\hline $\begin{array}{l}\text { Midbrain } \\
\text { areas }\end{array}$ & \multicolumn{2}{l}{ Postnatal days } \\
\cline { 2 - 4 } & $\mathbf{8}^{\mathrm{a}}$ & $\mathbf{2 0 ^ { \mathrm { b } }}$ & $\mathbf{9 0}^{\mathrm{c}}$ \\
\hline SNc & 100.0 & 67.3 & 36.6 \\
VTA & 95.3 & 92.2 & 67.0 \\
IFN & 97.6 & 92.3 & 99.7 \\
RDF & 100.0 & 56.9 & 71.8 \\
\hline
\end{tabular}

Notes: ${ }^{a, b, c}$ Data from Martí and colleagues, ${ }^{49}$ Bayer and colleagues, ${ }^{47}$ and Martí and colleagues. $^{50}$

Abbreviations: SNc, substantia nigra pars compacta; VTA, ventral tegmental area; IFN, interfascicular nucleus; RDF, retrorubral field.

DA-cell loss in each anatomically matched level. Within the $\mathrm{SNc}$, cell deficit means that in L1 only $42.5 \%$ of cells remain as compared to +/+ animals; this loss is greater in L2 and L3 (with only $38.5 \%$ and $32 \%$ of cells, respectively as compared to control) and greatest in L4 (25\%). In the weaver VTA, L2 exhibits rates of $64 \%$, L3 of $58 \%$, whereas in L4, the latest in the sequence, cell percentages are around $47 \%$ relative to controls. Two facts emerged from these data: (I) cell loss was always more intense at every SNc level than in the VTA ones, and (II) depletion of DA neurons increases along the AP axis of both midbrain regions.

Generative timetables of these DA cells were compared between $+/+$ and $w v / w v$ at the previously mentioned anatomical levels. In Figures 7 (for SNc) and 8 (for VTA), the frequencies of newborn neurons are graphically displayed. As can be seen, the span of neurogenesis is similar for both genotypes irrespective of the level considered, but there are systematic differences between the neurogenetic programs. Thus, the posterior levels of the $w v / w v \mathrm{SNc}$ and VTA (L3 and L4), which present a greater loss of neurons, also exhibit the most important profile shift toward earlier neurogenesis. In contrast, those with lower depletion (anterior levels) have a lower shift in their generative profiles. In other words, in every weaver SNc or VTA level, the mixed DA neurons were predominantly late-generated.

In a subsequent estimate, the neurogenetic gradients of DA neurons were also assessed for each selected level. Tables 7 and 8 show the proportions of early- and late-generated DA cells in $+/+$ and $w v / w v$ for the SNc and VTA, respectively.

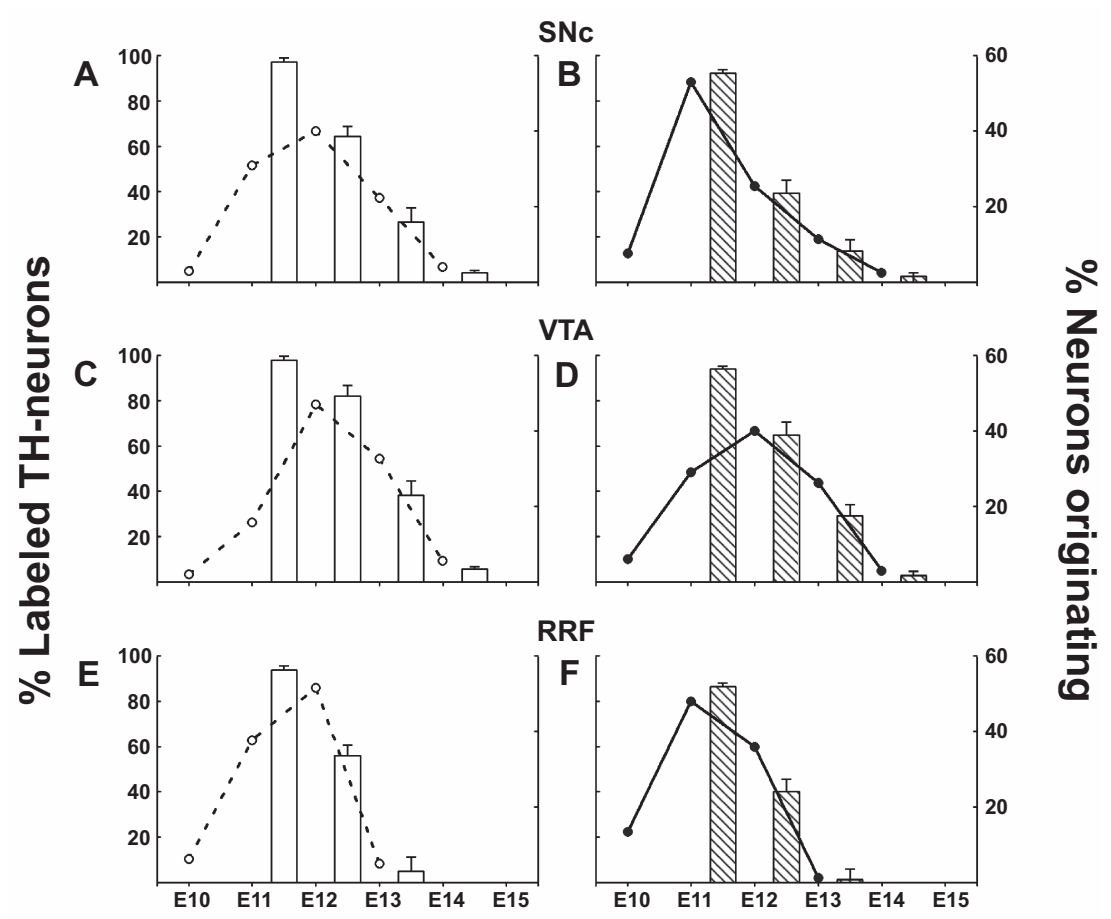

Embryonic day

Figure 6 Comparison of generative timetables between wild-type and weaver DA cells in three midbrain areas, the SNc (A, B), VTA (C, D), and RRF (E, F). Frequency histograms (left ordinate) of DA cells labeled with $\left.{ }^{3} \mathrm{H}\right] \mathrm{TdR}$ on two successive days of the embryonic period (abscissa) and surviving until P90. Empty and shared columns represent $+/+$ and $w v / w v$ respectively; percentages are expressed as mean \pm SEM. The inferred frequencies of newly generated DA cells for $+/+($ open circles and broken line) and $w v / w v$ (closed circles and solid lines) are also plotted. Percentages of these newborn neurons (right ordinate) were determined by the rate of decline in labeled cells at that time point. Data from Martí and colleagues. ${ }^{50}$ 


\section{L1}

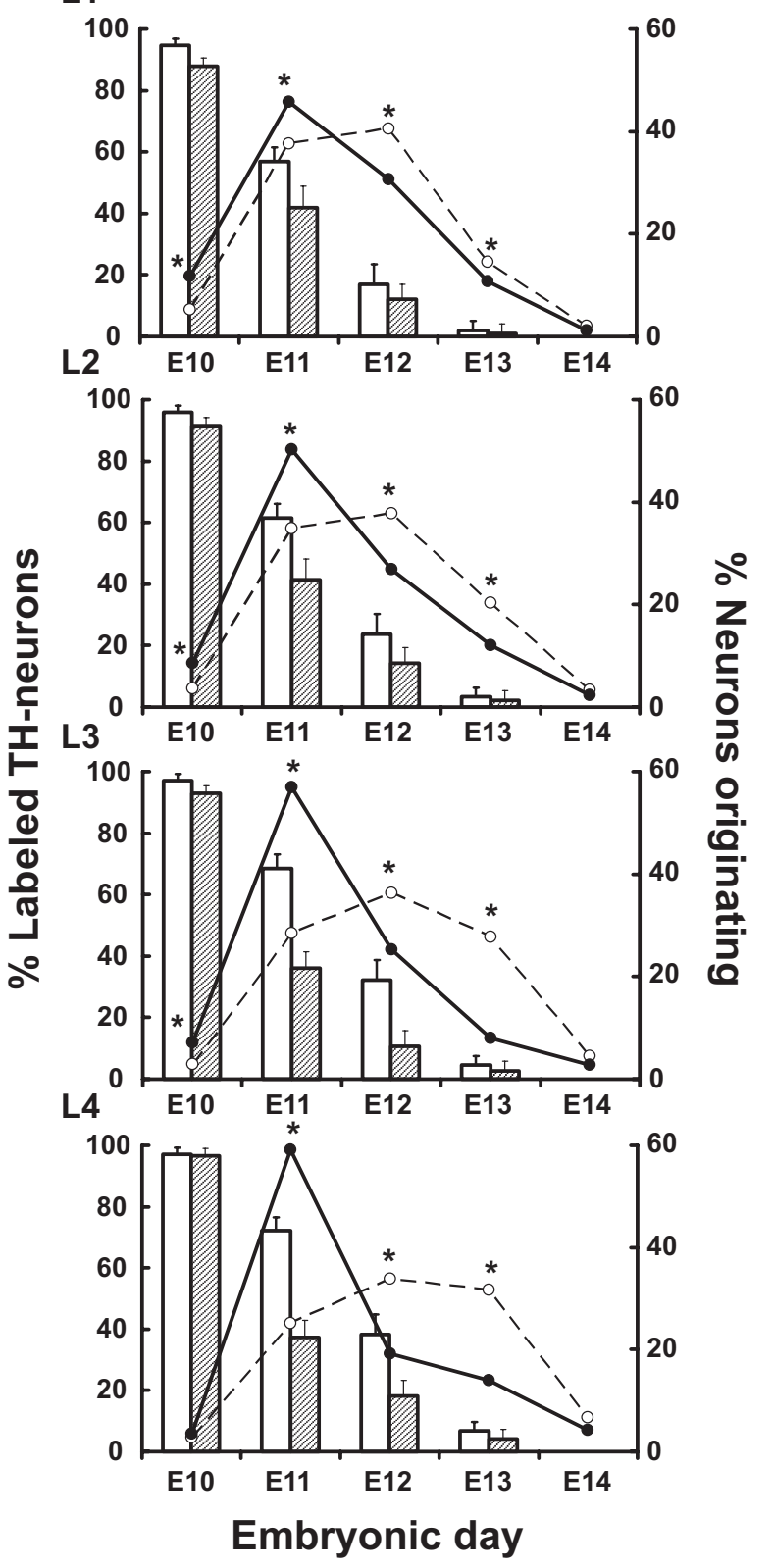

Figure 7 Comparison of neurogenetic patterns between wild-type and weaver DA cells along the AP axis of the SNc anatomical levels: LI, L2, L3 and L4. Frequency histograms of TH neurons labeled with $\left[{ }^{3} \mathrm{H}\right] \mathrm{TdR}$ on two successive days of the embryonic period and survival until P90. White and shared columns represent $+/+$ and wv/wv respectively; percentages are expressed as mean \pm SEM.The neurogenetic timetables for $+/+$ (open circles and broken line) and $w v / w v$ (closed circles and solid line) are also plotted. Percentages of newborn neurons (right ordinate) were determined by the rate of decline in labeled cells at that time point. Note that the wild group has a peak time of origin located on EI2 at each level considered, whereas the wv/wv have such a peak on EII. Asterisks denote significant differences $(P<0.05)$ between means. Copyright @ 2007 , Elsevier. Adapted with permission from Martí J, Santa-Cruz MC Bayer SA, Ghetti B, Hervás JP. Generation and survival of midbrain dopaminergic neurons in weaver mice. Int J Devl Neurosci. 2007;25(5):299-307.

At least two basic observations can be drawn. First, for both genotypes, every SNc anatomical level has more earlyformed neurons than in any VTA position. Second, the frequency of $+/+$ oldest neurons follows an AP decline, whereas there is an increase in the number of the youngest cells.

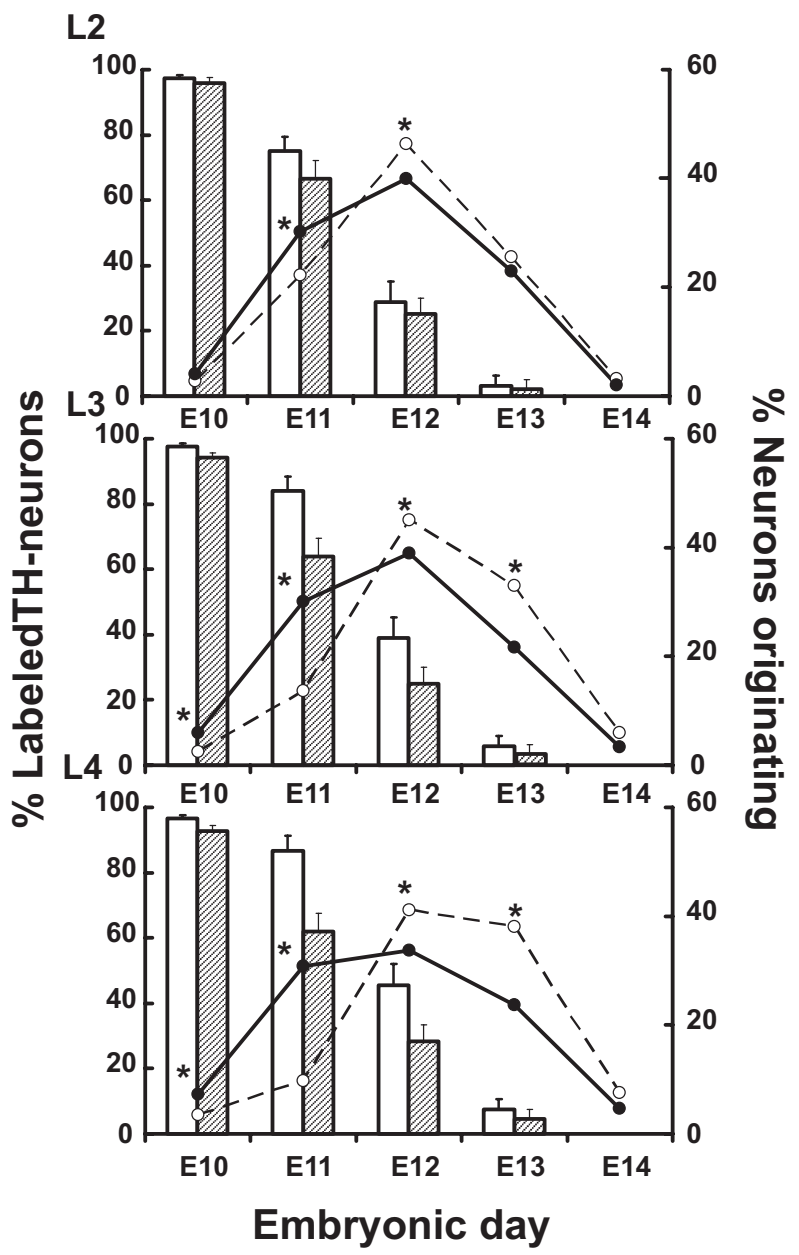

Figure 8 Comparison of inferred neurogenetic patterns between wild-type and weaver DA cells along the AP axis of the VTA: L2, L3, and L4. See legend in Figure 7 for an explanation of plotted data. Note that both the control and mutant group have peak time of origin located on EI2, even though the percentages of surviving DA neurons born at EI 2 and EI 3 are statistically lower in the mutant group than in the control. Asterisks denote significant differences $(P<0.05)$ between means. Copyright (C) 2007, Elsevier. Adapted with permission from Martí J, Santa-Cruz MC, Bayer SA, Ghetti B, Hervás JP. Generation and survival of midbrain dopaminergic neurons in weaver mice. Int J Devl Neurosci. 2007;25(5):299-307.

Such an increase of SNc-VTA late-produced DA neurons was disturbed in weaver as a consequence of the increasing AP loss of these cells. In short, the number of surviving DA cells in the mutant condition is closely linked to the actual age of such neurons.

\section{Discussion}

\section{Generation and distribution of surviving weaver PCs}

Several comparative studies about $\mathrm{PC}$ generation and settling in wild-type and homozygous weaver mice are reviewed here. ${ }^{26,39,40,45,46}$ Separate analyses are carried out in sagittal sections, making a distinction between the mediolateral and anteroposterior cerebellar axes as well as between the two surface compartments of the cortex: fissures and 
Table 7 Frequency of generated DA neurons in the substantia nigra pars compacta

\begin{tabular}{llllll}
\hline $\begin{array}{l}\text { Anatomical } \\
\text { levels }\end{array}$ & \multicolumn{2}{l}{ Older $(E I 0+I I)$} & & \multicolumn{2}{c}{ Younger $(E I 3+I 4)$} \\
\cline { 2 - 3 } \cline { 6 - 6 } & $+/+$ & $w v / w v$ & & $+/+$ & $w v / w v$ \\
\hline LI & 42.9 & 57.6 & & 16.6 & 11.8 \\
L2 & 38.4 & 58.7 & & 23.8 & 14.4 \\
L3 & 31.4 & 64.1 & & 32.3 & 10.6 \\
L4 & 27.9 & 62.6 & 38.3 & 18.2 \\
\hline
\end{tabular}

Notes: Percentage of early and late-generated dopaminergic cells in each SNc level. Dopaminergic neurons formed at EIO and EII are considered early formed, whereas those produced at EI3 and EI4 are late generated. Copyright (C) 2007, Elsevier. Adapted with permission from Martí J, Santa-Cruz MC, Bayer SA, Ghetti B, Hervás JP. Generation and survival of midbrain dopaminergic neurons in weaver mice. Int J Devl Neurosci. 2007;25(5):299-307.

foliar crowns. Our basic observation is that in each particular studied region of the cerebellar cortex, PC neurogenesis is similar for $+/+$ and $w v / w v$ mice. We have also presented evidence that in every vermal lobe, or hemispheric lobule, as well as in grooves and creases of the vermal or hemispheric contour, surviving PCs at P90 are spatially distributed according to precise neurogenetic gradients, which closely resemble those of the control group.

One implication of that mentioned above is the existence of some $w v / w v$ PC populations that are able to migrate properly from the ventricular neuroepithelium to their apparent final destinations. There is no contradiction here with the well-known cytoarchitectonic derangement of PCs throughout the weaver cerebellar cortex, ${ }^{22,23}$ because such an ectopic position is also associated with an almost complete absence of GCs. In other words, cellular tenure of mutated GIRK2 protein does not prevent the migration and settling of surviving PCs.

Table 8 Frequency of generated DA neurons in the ventral tegmental area

\begin{tabular}{llllll}
\hline $\begin{array}{l}\text { Anatomical } \\
\text { levels }\end{array}$ & \multicolumn{2}{l}{ Older $(E I 0+I I)$} & & \multicolumn{2}{c}{ Younger $(E I 3+$ I4) } \\
\cline { 2 - 3 } \cline { 5 - 6 } & $+l+$ & wv/wv & & $+/+$ & wv/wv \\
\hline L2 & 24.9 & 33.3 & & 28.8 & 26.7 \\
L3 & 16.1 & 30.8 & & 38.9 & 30.2 \\
L4 & 13.3 & 37.9 & & 45.6 & 28.4 \\
\hline
\end{tabular}

Notes: Percentage of early and late-generated dopaminergic cells in each VTA level. Dopaminergic neurons formed at EIO and EII are considered early formed, whereas those produced at EI3 and EI4 are late generated. Copyright (C) 2007, Elsevier. Adapted with permission from Martí J, Santa-Cruz MC, Bayer SA, Ghetti B, Hervás JP. Generation and survival of midbrain dopaminergic neurons in weaver mice. Int J Devl Neurosci. 2007;25(5):299-307.

\section{Cell loss versus PC age-distribution}

A significant amount of PCs is lost in the weaver cerebellum. ${ }^{22-24,52,53}$ Our results also showed a substantial reduction in the number of PCs at P90 in most cortical regions studied. However, our main goal with regard to the postnatal period was to find out whether the age of $w v / w v$ PCs could predispose them to a long or short survival. The analysis consisted in comparing the neurogenetic gradient of PCs in each particular cortical zone with the corresponding numerical depletion, by following the two anatomical axes of the cerebellum. Thus, in the mediolateral axis, the so-called vermal compartment ${ }^{41}$ exhibits the highest proportion of lategenerated PCs and sustains the most dramatic losses. Along the anteroposterior axis, however, the late-formed PCs are accumulated in the anterior lobe, that is, the vermal region with fewer missing PCs. Hence, a numerical deficit seems to be unrelated to the local age-distribution of surviving PCs and, therefore, it is tempting to assume that the weaver gene may be targeting PCs irrespective of their birthdates.

The present study also contributes information about an interesting aspect related to cerebellar cortex development, which is the possible relationship between PC age and fissuration pattern. Consistent with early data from normal mouse cerebella, ${ }^{54}$ an unbalanced age-distribution of PCs between fissures and foliar crowns has been found in both wild-type and mutant genotypes. ${ }^{40}$ Moreover, although numerical depletion in weaver can be related to foliar concavities or convexities depending on the vermal lobe analyzed, the late-generated PCs are always preferentially located in fissures. We do not know why this occurs but, a priori, the PC developmental program should be taken into consideration. In rodent embryos, the incipient vermal lobes comprise five populations or clusters of PCs, which are distributed following a strict temporal order: beginning on the central lobe, composed of early-generated cells, and ending on the anterior lobe, which contains later-produced PCs, according to a caudorostral gradient. ${ }^{41,55}$ Interestingly, current disparities in PC depletion between fissures and foliar crowns are restricted to the younger PC clusters, that is, those from the inferior and anterior vermal lobes, while the anterior lobe itself exhibits the smallest PC loss in its fissures. These observations led us to propose two time periods for the deleterious action of the weaver mutation on PCs. During the first period, cell depletion would equally affect PC cohorts destined to move toward both the presumptive fissures and surface convexities of the ontogenetically older vermal cortical locations: the central and posterior lobes. In a second period, the remaining PCs destined to colonize 
other lobes would be progressively less affected by the mutant gene. This might result in different stages of vulnerability for those neurons assigned to concave versus convex surfaces, the cell loss being less important in those foliar compartments in which late-generated PCs prevail, such as the fissures of the anterior vermal lobe.

\section{GIRK channel diversity and PC survival}

At this point in the discussion, an important question arises: if the decrease in PC numbers is due to a direct action of the weaver mutation, ${ }^{52}$ why do some PCs carrying the mutated gene die and others do not? We are very far from being able to provide a clear answer, but the existence of the mutated protein GIRK2wv must be close to the heart of the matter.

Most PCs in the adult normal mouse express both Girk2 mRNA and GIRK2 protein, although at low detection levels, and the immunoreactivity is typically present in dendrites and the neuropil. ${ }^{20,56}$ The residual PCs in the homozygous weaver continue to express GIRK2. ${ }^{20,57}$ Therefore, other factors besides the mere presence of GIRK $2 w v$ must also be involved in the potentially lethal effect of the mutated GIRK2 channel subunit. For example, the constitution of channels themselves should be taken into consideration. Splicing of the Girk2 gene yields multiple isoforms of Girk2 transcripts, ${ }^{8,58,59}$ while other members of the GIRK family, such as GIRK1 and GIRK3 are also expressed in PCs of adult mice and rats. ${ }^{17,56}$ Although neuronal GIRK channels are often considered to consist primarily of GIRK2 homotetramers ${ }^{60,61}$ or GIRK1/GIRK2 heterotetramers, ${ }^{9,62}$ other subunit combinations can be present in PCs, such as GIRK1/GIRK2/GIRK3 heteromeric complexes, as suggested by recent co-immunoprecipitation experiments. ${ }^{56}$ Moreover, the toxic effect of the $w v$ allele, when expressed in heterologous systems, can be reduced by heteropolymerization with all other members of the GIRK family. ${ }^{63}$ Thus, the different levels of vulnerability of PCs along the cerebellar cortex, previously mentioned, might reflect the GIRK channel diversity. It is conceivable that the relative contribution of GIRK3 subunits to heterotetrameric channel assembly would be able to compensate for the GIRK $2 w v$ in those PCs that survive.

Another important factor, also related to the suggested interaction between channel subunits, could be the timing of the expression of the Girk genes during normal PC development. The low level of Girk1 mRNA seems to undergo little fluctuation throughout the embryonic and postnatal mouse development. ${ }^{64}$ However, the expression of the other two PC Girk genes shows developmental regulation. The levels of Girk2 RNA and GIRK2 protein become progressively weaker from neonates to P22, ${ }^{57,60,64}$ while the Girk3 mRNA increases from $\mathrm{P} 0$, and becomes the predominant transcript from 10 days after birth. ${ }^{64}$ Once again, this suggests a likely role in PC rescue played by the GIRK3 subunit in the weaver channel assembly. Yet, it also implies the existence, a priori, of a time period of maximum cellular susceptibility to the nocive effects of the GIRK2wv subunit. Such a scenario has parallels with our model of decreasing vulnerability of $w v / w v$ PCs in early developmental times, previously described above in Cell loss versus PC age-distribution. Nevertheless, the sole contribution of GIRK3 cannot in itself be the algorithm for cell survival of weaver PCs; other intrinsic and extrinsic cellular factors could converge to affect the life expectancy of these macroneurons.

\section{Relationship between DA-cell age and neurodegeneration}

The second part of current results deals with the weaver DA neurons from four areas of the mouse ventral midbrain: the SNc, VTA, IFN, and RRF. We review the information about this subject taken from a series of our own papers. ${ }^{46-50}$ Working at an early postnatal age, ie, at P8, we found no depletion in the DA-cell number, while the weaver gene seemed to have no apparent effect on the settling of DA cells in the midbrain areas studied, or on the mitotic activity of their precursors. In the adult weaver mouse, however, only the IFN escapes the spontaneous degeneration of DA neurons. Furthermore, cell vulnerability is built into the other DA-cell groups during their late postnatal development.

At P90, however, the inferred generative timetables of DA neurons are systematically different between weaver and control in the SNc, VTA, and RRF. Yet, all these neurogenetic profiles show a common feature in the mutant group: the shift of the peak of the profile to early embryonic days. This means that the late-generated DA cells are more liable to suffer the lethal effect of the weaver gene than those generated earlier. In other words, the survival of $w v / w v$ DA neurons in all these midbrain areas is related to cellular age.

\section{Regional variability in DA-cell loss and GIRK channels}

We have examined four DA-cell groups in the ventral midbrain of $+/+$ and $w v / w v$ mice looking for some relationship between cell-age and cell-survival. As only one of these mesencephalic areas, the IFN, escapes cell death, it may be interesting to analyze the relative distribution of GIRK $2 w v$. A previous comparative study in normal 
mice, by in situ hybridization and immunohistochemistry, showed that only the DA neurons of the SNc, VTA and RRF expressed the GIRK2 subunit, suggesting that these cells may be direct primary targets for weaver mutation. ${ }^{20}$ Within the three DA-cell groups, the most prominent levels of Girk2 mRNA and GIRK2 immunoreactivity were detected in the SNc, ${ }^{9,20,62}$ which is the area most susceptible to cell death. ${ }^{37,65}$ Moreover, the remaining $w v / w v$ DA neurons of all these areas also expressed GIRK2 in both young and adult weaver mice. ${ }^{9,20}$

The relative contribution of other subunits to the mutated GIRK channel does not seem to be correlated with selective cell vulnerability in each midbrain area mentioned. Most studies on the SNc and VTA were unable to detect or could barely detect Girk 1 mRNA. 10,62,64,66 Other reports have indicated that Girk3 transcripts are expressed throughout both regions, albeit at low levels. ${ }^{17,64,67,68}$ Nevertheless, there is a wide consensus that, under normal conditions, GIRK2 homomers, or GIRK2A/2C, ${ }^{10}$ are the prevailing functional channel assembly. Some differences in splice isoform overexpression of the Girk2 gene among midbrain areas could perhaps explain cellular changes in the altered function of the GIRK2wv channel.

\section{Intraregional vulnerability of weaver DA neurons}

Finally, our study focused on the two major DA-cell groups of the ventral midbrain: the SNc and the VTA. We analyzed the spatial distribution of $+/+$ and $w v / w v$ DA neurons throughout the AP extent of both mesencephalic areas. ${ }^{51}$ This is an extension of other studies in which cell counts were undertaken along the mediolateral axis of the developing nigral complex. ${ }^{37}$ In our study, neurogenetic data from both the SNc and VTA revealed that survival of $w v / w v$ DA cells is closely linked to neuronal age itself, irrespective of the AP anatomical level analyzed. In addition, the weaver-induced cell loss in both regions followed an AP gradient of increasing severity. Thus, the $w v / w v$ neurons at the posterior parts of the SNc or the VTA were more susceptible to the lethal action of the mutated gene than were those located at the anterior levels. This pattern of vulnerability bears similarities to that described in idiopathic Parkinson's disease (PD). Indeed, in adult human patients, the DA neurons located rostrally in the SNc are more resistant to cell death than those located caudally. ${ }^{69,70}$ However, the weaver condition presents a generational feature: the greatest cell loss occurs in those AP levels that contain the highest proportion of late-generated neurons.
There is still insufficient information about GIRK channels for us to be able to explain the neurodegenerative AP gradient seen within both $w v / w v$ SNc and VTA, but the lethal effect of the weaver gene must depend upon a combination of the abnormal function of GIRK $2 w v$ subunit and other factors specific to the vulnerable DA cells. For example, there could be some defaults in the availability of trophic factors during the synaptic period of DA neurons from either the SNc, which give rise to the nigrostriatal pathway, or from the VTA, which give rise to the mesolimbic and mesocortical pathways. In this context, it is well documented that glial cell line-derived neurotrophic factors potently promote the survival ability of SNc DA cells in animal models of PD, ${ }^{71,72}$ as well as in weaver and human clinical trials. ${ }^{73,74}$

\section{Disclosures}

The authors report no conflicts of interest in this work.

\section{References}

1. Jan LY, Jan YN. Cloned potassium channels from eukaryotes and prokaryotes. Annu Rev Neurosci. 1997;20:91-123.

2. Harkins AB, Fox AP. Cell death in weaver cerebellum. The Cerebellum. 2002;1:201-206.

3. Sadja R, Alagem N, Reuveny E. Gating of GIRK channels: details of an intrincate membrane-delimited signaling complex. Neuron. 2003;39:9-12.

4. Stanfield PR, Nakajima S, Nakajima Y. Constitutively active and G-protein coupled inward rectifier $\mathrm{K}^{+}$channels: Kir2.0 and Kir3.0. Rev Physiol Biochem Pharmacol. 2002;145:47-179.

5. Kobayashi T, Ikeda K, Ichikawa T, Abe S, Togashi S, Kumanishi T. Molecular cloning of a mouse G-protein-activated $\mathrm{K}^{+}$channel (mGIRK1) and distinct distributions of three GIRK (GIRK1, 2 and 3) mRNAs in mouse brain. Biochem Biophys Res Commun. 1995;208: $1166-1173$.

6. Krapivinsky G, Gordon EA, Wickman K, Velimirovic B, Krapivinsky L, Clapham DE. The G-protein-gated atrial $\mathrm{K}^{+}$channel IKACh is a heteromultimer of two inwardly rectifying $\mathrm{K}^{+}$channel proteins. Nature. 1995;374:135-141.

7. Wickman K, Karschin C, Karschin A, Picciotto MR, Clapham DE. Brain localization and behavioral impact of the G-protein-gated $\mathrm{K}^{+}$channel subunit GIRK4. J Neurosci. 2000;20:5608-5615.

8. Lesage F, Guillemare E, Fink M, et al. Molecular properties of neuronal G-protein-activated inwardly rectifying $\mathrm{K}^{+}$channels. J Biol Chem. 1995;270:28660-28667.

9. Liao YJ, Jan YN, Jan LY. Heteromultimerization of G-protein-gated inwardly rectifying $\mathrm{K}^{+}$channel proteins GIRK1 and GIRK2 and their altered expression in weaver brain. J Neurosci. 1996;16:7137-7150.

10. Inanobe A, Yoshimoto $\mathrm{Y}$, Horio $\mathrm{Y}$, et al. Characterization of G-protein-gated $\mathrm{K}^{+}$channels composed of Kir3.2 subunits in dopaminergic neurons of the substantia nigra. J Neurosci. 1999;19: 1006-1017.

11. Kofuji P, Davidson N, Lester HA. Evidence that neuronal G-protein-gated inwardly rectifying $\mathrm{K}^{+}$channels are activated by $\mathrm{G}$ beta gamma subunits and function as heteromultimers. Proc Natl Acad Sci U S A. 1995;92:6542-6546.

12. Ma D, Zerangue N, Raab-Graham K, Fried SR, Jan YN, Jan LY. Diverse trafficking patterns due to multiple traffic motifs in $\mathrm{G}$ protein-activated inwardly rectifying potassium channels from brain and heart. Neuron. 2002;33:715-729. 
13. Jelacic TM, Kennedy ME, Wickman K, Clapham DE. Functional and biochemical evidence for G-protein-gated inwardly rectifying $\mathrm{K}^{+}$(GIRK) channels composed of GIRK2 and GIRK3. J Biol Chem. 2000;275:36122-36216.

14. Cheng SV, Nadeau JH, Tanzi RE, et al. Comparative mapping of DNA markers from familial Alzheimer disease and Down syndrome regions of human chromosome 21 to mouse chromosomes 16 and 17. Proc Natl Acad Sci U S A. 1988;85:6032-6036.

15. Reeves RH, Crowley MR, Lorenzon N, Pavan WJ, Smeyne RJ, Goldowitz D. The mouse neurological mutant weaver maps within the region of chromosome 16 that is homologous to human chromosome 21 . Genomics. 1989;5:522-526.

16. Patil N, Cox DR, Bhat D, Faham M, Myers RM, Peterson AS A potassium channel mutation in weaver mice implicates membrane excitability in granule differentiation. Nature Genet. 1995;11 126-129.

17. Karschin C, Dissman E, Stühmer W, Karschin A. IRK(1-3) and GIRK(1-4) inwardly rectifiying $\mathrm{K}^{+}$channel mRNA are differentially expressed in the adult rat brain. J Neurosci. 1996;16:3559-3570.

18. Wei J, Dlouhy SR, Bayer S, et al. In situ hybridization analysis of Girk2 expression in the developing central nervous system in normal and weaver mice. J Neuropathol Exp Neurol. 1997;56(7):762-771.

19. Sekiguchi M, Nowakowski RS, Nagato Y, et al. Morphologial abnormalities in the hippocampus of the weaver mutant mouse. Brain Res. 1995;696:262-267.

20. Schein JC, Hunter DD, Roffler-Tarlov S. Girk2 expression in the ventral midbrain, cerebellum, and olfactory bulb and its relationship to the murine mutation weaver. Dev Biol. 1998;204:432-450.

21. Savy C, Martín-Martinelli E, Simon A, et al. Altered development of dopaminergic cells in retina of weaver mice. J Comp Neurol. 1999;412:656-668.

22. Rezai $\mathrm{Z}$, Yoon $\mathrm{CH}$. Abnormal rate of granule cell migration in the cerebellum of weaver mutant mice. Dev Biol. 1972;29:17-26.

23. Rakic P, Sidman RL. Sequence of developmental abnormalities leading to granule cell deficit in cerebellar cortex of weaver mutant mice. J Comp Neurol. 1973;152:103-132.

24. Blatt BJ, Eisenman LM. A quantitative and quantitative light microscopic study of the inferior olivary complex of normal, reeler, and weaver mutant mice. J Comp Neurol. 1985;232:117-128.

25. Smeyne RJ, Goldowitz D. Developmental and death of external granular layer cells in the weaver mouse cerebellum: a quantitative study. J Neurosci. 1989;9:1608-1620.

26. Martí J, Wills KV, Ghetti B, Bayer SA. Evidence that the loss of Purkinje cells and deep cerebellar nuclei neurons in homozygous weaver is not related to neurogenetic patterns. Int J Devl Neurosci. 2001;19:599-610.

27. Goldowitz D, Mullen RJ. Granule cell as a site of gene action in the weaver mouse cerebellum: evidence from heterozygous mutant chimeras. J Neurosci. 1982;2:1474-1485.

28. Herrup K, Trenkner E. Regional differences in cytoarchitecture of the weaver cerebellum suggest a new model for weaver gene action. Neuroscience. 1987;23:871-885.

29. Eisenman LM, Gallagher E, Hawkes R. Regionalization defects in the weaver cerebellum. J Comp Neurol. 1998;394:431-444.

30. Armstrong C, Hawkes R. Selective Purkinje cell ectopia in the cerebellum of the weaver mouse. J Comp Neurol. 2001;439: $151-161$.

31. Ozaki M, Hashikawa T, Ikeda K, et al. Degeneration of pontine mossy fibers during cerebellar development in weaver mutant mice. Eur $J$ Neurosci. 2002;16:565-574.

32. Lalonde R, Strazielle C. Spontaneous and induced mouse mutations with cerebellar dysfunctions: behavior and neurochemistry. Brain Research. 2007;1140:1-74

33. Lane JD, Nadi NS, McBride WJ, Aprison MH, Kusano K. Content of serotonin, norepinephrine and dopamine in the cerebrum of the "staggerer", "weaver" and "nervous" neurologically mutant mice. J Neurochem. 1977;29:349-350.
34. Schmidt MJ, Sawyer BD, Perry KW, Fuller RW, Foreman MM, Ghetti B. Dopamine deficiency in the weaver mutant mouse. J Neurosci. 1982;2:376-380.

35. Triarhou LC, Norton J, Ghetti B. Mesencephalic dopamine cell deficit involves areas A8, A9 and A10 in weaver mutant mice. Exp Brain Res. 1988;70:256-265.

36. Verney C, Febvret-Muzerelle A, Gaspar P. Early postnatal changes of the dopaminergic mesencephalic neurons in the weaver mutant mouse. Dev Brain Res. 1995;89:115-119.

37. Roffler-Tarlov S, Martin B, Graybiel AM, Kauer JS. Cell death in the midbrain of the murine mutation weaver. J Neurosci. 1996;16: 1819-1826.

38. Martí J, Wills KW, Ghetti B, Bayer SA. A combined immunohistochemical and autoradiographic method to detect midbrain neurons and determine their time of origin. Brain Res Protoc. 2002;9:197-205.

39. Martí J, Wills KW, Ghetti B, Bayer SA. Regional differences in the Purkinje cells settled pattern: a comparative autoradiographic study in control and homozygous weaver mice. Exp Neurol. 2002; 175:168-181.

40. Martí J, Santa-Cruz MC, Bayer SA, Ghetti, B, Hervás, JP. Purkinje cell age-distribution in fissures and in foliar crowns: a comparative study in the weaver cerebellum. Brain Struct Funct. 2007;212:347-357.

41. Altman J, Bayer SA. Development of the cerebellar system in relation to its evolution, structure and functions. Boca Raton, FL: CRC Press; 1997.

42. Lange W. Regional differences in the cytoarchitecture of the cerebellar cortex. In: Palay SL, Chan-Palay V, editors. The cerebellum: new vistas. Berlin, Germany: Springer-Verlag; 1982. p. 93-107.

43. Sidman RL, Angevine JB, Taber-Pierce E. Atlas of the mouse brain and spinal cord. Cambridge, MA: Harvard University Press; 1971.

44. Bayer SA, Altman J. Neurogenesis and neuronal migration. In: Patxinos G, editor. The rat nervous system. San Diego, CA: Academic Press; 1995. p. 1041-1078.

45. Bayer SA, Wills KV, Wei J, et al. Phenotypic effects of the weaver gene are evident in the embryonic cerebellum but not in the ventral midbrain. Dev Brain Research. 1996;96:130-137.

46. Martí J, Santa-Cruz MC, Bayer SA, Hervás JP. The weaver gene expression affects neuronal generation patterns depending on age and encephalic region. Neurosci Lett. 2006;396(3):202-206.

47. Bayer SA, Wills KV, Triarhou LC, Thomas JD, Ghetti B. Systematic differences in time of dopaminergic neuron origin between normal mice and homozygous weaver mutants. Exp Brain Res. 1995;105: 200-208.

48. Bayer SA, Wills KV, Triarhou LC, Verina T, Thomas JD, Ghetti B. Selective vulnerability of late-generated dopaminergic neurons of the substantia nigra in weaver mutant mice. Proc Natl Acad US A. 1995;92:9137-9140.

49. Martí J, Wills KW, Ghetti B, Bayer SA. The weaver gene has no effect on the generation patterns of mesencephalic dopamine neurons. Dev Brain Res. 2000;122:65-172.

50. Martí J, Wills KW, Ghetti B, Bayer SA. The weaver gene continues to target late-generated dopaminergic neurons in midbrain areas at P90. Dev Brain Res. 2000;122:173-181.

51. Martí J, Santa-Cruz MC, Bayer SA, Ghetti B, Hervás JP. Generation and survival of midbrain dopaminergic neurons in weaver mice. Int $J$ Devl Neurosci. 2007;25(5):299-307.

52. Smeyne RJ, Goldowitz D. Purkinje cell loss is due to a direct action of the weaver gene in Purkinje cells: evidence from chimeric mice. Dev Brain Res. 1990;52:211-218.

53. Maricich SM, Soha J, Trenkner E, Herrup K. Failed cell migration and death of Purkinje cells and deep nuclear neurons in the weaver cerebellum. J Neurosci. 1997;17:675-3683.

54. Inouye M, Murakami U. Temporal and spatial patterns of Purkinje cell formation in the mouse cerebellum. J Comp Neurol. 1980; 194:499-503.

55. Yuasa S, Kawamura K, Ono K, Yamakumi T, Takahashi T. Development and migration of Purkinje cells in the mouse cerebellar primordium. Anat Embryol. 1991;184:195-212. 
56. Aguado C, Colón J, Ciruela F, et al. Cell type-specific subunit composition of $\mathrm{G}$ protein-gated potassium channels in the cerebellum. J Neurochem. 2008;105:497-511.

57. Lauritzen I, De Weille J, Adelbrecht C, et al. Comparative expression of the inward rectifier $\mathrm{K}^{+}$channel GIRK2 in the cerebellum of normal and weaver mice. Brain Res. 1997;753:8-17.

58. Isomoto S, Kondo C, Takahashi N, et al. A novel ubiquitously distributed isoform of GIRK2 (GIRKb) enhances GIRK1 expression of the G-protein-gated $\mathrm{K}^{+}$current in Xenopus oocytes. Biochem Biophys Res Commun. 1996;218:286-291.

59. Wei J, Hodes ME, Piva R, et al. Characterization of murine Girk2 transcript isoforms: structure and differentiatial expression. Genomics. 1998;51:379-390.

60. Slesinger PA, Patil N, Liao YJ, Jan YN, Jan LY, Cox DR. Functional effects of the mouse weaver mutation on $\mathrm{G}$ protein-gated inwardly rectifying $\mathrm{K}^{+}$channels. Neuron. 1996;16:321-331.

61. Schoots O, Wilson JM, Ethier N, Bigras E, Hebert TE, Van Tol HH. Co-expression of human Kir3 subunits can yield channels with different functional properties. Cell Signal. 1999;11:871-883.

62. Koyrakh L, Lujan R, Colón J, et al. Molecular and cellular diversity of neuronal G-protein-gated potassium channels. J Neurosci. 2005;25: 11468-11478.

63. Tucker SJ, Pessia M, Moorhouse AJ, et al. Heteromeric channel formation and $\mathrm{Ca}^{2+}$-free media reduce the toxic effect of the weaver $\mathrm{K}_{\text {ir }} 3.2$ allele. FEBS Lett. 1996;390:253-257.

64. Chen SC, Ehrhard P, Goldowitz D, Smeyne RJ. Developmental expression of the GIRK family of inward rectifying potassium channels: implications for abnormalities in the weaver mutant mouse. Brain Res. 1997;778:251-264.

65. Graybiel AM, Ohta K, Roffler-Tarlov S. Patterns of cell and fiber vulnerability in the mesostriatal system of the mutant mouse weaver. I. Gradients and compartments. J Neurosci. 1990;10(3):720-733.
66. Harashima C, Jacobowitz DM, Witta J, et al. Abnormal expression of the G-protein activated inwardly rectifying potassium channel 2 (GIRK2) in hippocampus, frontal cortex, and substantia nigra of Ts65Dn mouse: a model of Down syndrome. J Comp Neurol. 2006;494:815-833.

67. Liss B, Neu A, Roeper J. The weaver mouse gain-of-function phenotype of dopaminergic midbrain neurons is determined by coactivation of $w w$ Girk 2 and K-ATP channels. J Neurosci. 1999;15: 839-8848

68. Cruz HG, Ivanova T, Lunn ML, Stoffel M, Slesinger PA, Lüscher C. $\mathrm{Bi}$-directional effects of $\mathrm{GABA}(\mathrm{B})$ receptor agonists on the mesolimbic dopamine system. Nat Neurosci. 2004;7:153-159.

69. Matzuk MM, Saper CB. Preservation of hypothalamic dopaminergic neurons in Parkinson's disease. Ann Neurol. 1985;18:552-555.

70. Damier P, Hirsch EC, Agid Y, Graybiel AM. The substantia nigra of the human brain II. Patterns of loss of dopamine-containing neurons in Parkinson's disease. Brain. 1999;122:1437-1448.

71. Kordower JH, Emborg ME, Bloch J, et al. Neurodegeneration prevented by lentiviral vector delivery of GDNF in primate models of Parkinson's disease. Science. 2000;290:767-773.

72. Grondin R, Zhang Z, Yi A, et al. Chronic, controlled GDNF infusion promotes structural and functional recovery in advanced parkinsonian monkeys. Brain. 2002;125:2191-2201.

73. Broome JD, Will KV, Lapchak PA, Ghetti B, Camp LL, Bayer SA. Glial cell line-derived neurotrophic factor protects midbrain dopamine neurons from the lethal action of the weaver gene: a quantitative immunocytochemical study. Dev Brain Res. 1999;116:1-7.

74. Love S, Plaha P, Patel NK, Hotton GR, Brooks DJ, Gill SS. Glial cell line-derived neurotrophic factor induces neuronal sprouting in human brain. Nat Med. 2005;11:703-704.
Journal of Receptor, Ligand and Channel Research

\section{Publish your work in this journal}

The Journal of Receptor, Ligand and Channel Research is an international, peer-reviewed, open access, online journal. The journal welcomes laboratory and clinical findings in the fields of biological receptors, ligands, channel and signal transduction research including: receptors and signalling; ligands; transporters, pores and channels; binding and activation; receptor

\section{Dovepress}

regulation; role of receptors in diseases and their treatment; molecular basis of membrane structure and functions; molecular models of membranes. The manuscript management system is completely online and includes a very quick and fair peer-review system. Visit http://www.dovepress.com/ testimonials.php to read real quotes from published authors. 